\title{
Multipurpose Census Methodology to Assess Urban Forest Structure in Hong Kong
}

\author{
C.Y. Jim
}

\begin{abstract}
Surveys of urban forests in the compact city environment of Hong Kong were initiated in 1985 and regularly updated thereafter. Roadside trees were evaluated first in a tree census and reported in this article followed by urban parks, public housing estates, and special habitats such as old stone walls or special specimens such as heritage trees. The survey method aimed at collecting comprehensive data to echo both tree conditions and tree-environmental interactions. Detailed information was gleaned, with the help of well-trained assistants, on tree sites, tree growing space, tree structure, and tree defects and disorders. A field record form was designed, pilot-tested, and refined to solicit responses to multiple choices or direct measurements to minimize subjectivity and errors in data recording and entry. The study also identified potential planting sites, registering suitability for tree growth, site characteristics, and dimensions. Data fields were designed to be quantitative or convertible to ordinal ranks to facilitate statistical analysis. Locations of trees and planting sites were marked on large-scale maps to permit spatial analysis. Besides statistical analysis, community ecology attributes and custom-designed indices were used to assess urban forest structure. The multipurpose method could be appropriately adjusted for use in other compact city areas.
\end{abstract}

Key Words. Compact city; forest structure; heritage tree; Hong Kong; planting plan; species composition; species diversity; tree census.

Tree surveys have been widely used by urban foresters to collect objective and quantitative data on trees and their growth environment (Johannsen 1975; Weinstein 1983). Understanding the resource base provides the initial step to improve and rationalize urban forest management and raise the cost-benefit efficiency of tree programs (Tate 1985). The data could facilitate in-depth research into the tree-habitat relationship and evaluate the benefits and functions of urban greening. Whereas researchers are satisfied with a representative sample, many municipal authorities would adopt the inventory or census approach to study every tree within their jurisdiction.

The use of computer technology to store and analyze data was reported initially by McPherson et al. (1985) and Warrick and Williams (1993). Subsequently, developments in information technology triggered the application of the geographic information system (GIS) spatial analysis tools (Dwyer and Miller 1999; Pauleit and Duhme 2000). Street and park tree inventory has been conducted in different cities, exemplified by Chacalo et al. (1994) in Mexico City, Poracsky and Scott (1999) in Portland, Cheng et al. (2000) in Tokyo, Banks and Brack (2003) in Canberra, and Frank et al. (2006) in Greater Melbourne. Goodquality tree information gleaned from tree surveys is a key ingredient of sustainable urban forestry (Dwyer et al. 2003).

The urban forest in Hong Kong has been studied since the early 1980s. It began with roadside trees. The tree survey methodology was applied to trees planted or growing spontaneously in special ecologic habitats. They include trees of heritage value (Jim 1994a, 2004a, 2005), old stone retaining walls (Jim 1998a), urban parks (Jim 2000), new towns, institutional grounds, recreational beaches, and indoor shopping malls. Detailed data on approximately 40,000 urban trees have thus far been collected and used for research and management. A study on 40,000 trees in approximately 100 public housing estates is due for completion in mid-2008. The arboricultural and urban forestry research experience gained in Hong Kong has been applied to other Chinese cities, including Guangzhou, Nanjing (Jim and Liu 2001; Jim and Chen 2003), Shenzhen, and Taipei (Jim and Chen 2008).

The intensive urban tree studies in Hong Kong have yielded valuable data and insights into the conditions and constraints for tree growth in one of the most compact cities in the world. The findings contribute to the understanding of arboriculture and urban forestry in tropical cities. They have been used by tree managers and informed official policies on tree planting, protection, and management. This article has chosen the broad-based generic studies of roadside trees, complemented where appropriate by studies in other habitats, to illustrate the comprehensive assessment of urban forests in Hong Kong. It evaluates the objectives, scope, principles, methods, approaches of urban forestry research, and applications in Hong Kong. Besides biomass structure and species composition, the study explored the interplay between trees and the tight urban fabric and the potential to improve the quantity and quality of urban trees. The specific research objectives are: 1) to survey existing street trees; 2) to search for potential street-tree planting sites; 3) to interpret the results and offer recommendations; and 4) to design a master planting and management plan.

The survey covered all the public roads in the study area. Because the sampling intensity was $100 \%$, the study denoted a tree census.

\section{STUDY AREA AND METHODS}

\section{Where and When Was the Assessment Performed?}

The study was initiated in 1985 as a preliminary investigation (Jim 1986), in 1994 as a comprehensive tree census (Jim 1994b), and repeated in 2004 as a detailed study of a sample. In the intervening time, surveys were conducted on new roads and 
existing roads with newly planted trees or notable tree replacements. The study area covered the built-up parts of the core around Victoria Harbor. It included ten urban districts with 124 $\mathrm{km}^{2}$ (49.6 $\mathrm{mi}^{2}$ ) containing 3.28 million people in 0.94 million households. The exceptionally high development density in the compact city reaches an average of 26,452 persons $/ \mathrm{km}^{2}$, and peak spots exceed 100,000 persons $/ \mathrm{km}^{2}$. The city was founded in 1841, but most parts have been redeveloped to a high intensity, especially in the last four decades.

The developed areas have high coverage by buildings and roads with little spaces for greening. Built-up areas are often completely sealed by concrete, asphalt, or buildings and most roadsides have no planting strips or tree pits. Many development sites have $100 \%$ site coverage with no room left for intralot trees. Urban renewal tended to increase the site coverage and building density and eliminate existing trees and plantable spaces. Continual infilling of low-density sites often obliterated on-site trees. Pavements are narrow and heavily used with little chance for tree planting. Frequent road excavations and trenching regularly injure tree roots. The survey focused on roadside trees, which are the most cramped and stressful tree sites.

\section{What Data Were Collected?}

The study collected two sets of data. The first covered existing roadside trees with the help of a field record form (Table 1). It was pilot-tested and refined before actual data collection. It gathered detailed data on the roadside microhabitat, including general site conditions and specific tree growth space characterization. It then measured tree structural attributes followed by systematic assessment of critical morphologic symptoms of growth problems.

It was necessary to define the scope of the study to focus on the target trees. Roadside trees included those found in the following habitats: 1) pavement; 2) planting spaces in the form of tree lawn, tree strip, or raised planting bed that are situated between the curb and the property line; 3 ) incidental plots of public land that are physically contiguous to the pavement and construed as part and parcel of a street; 4) central divider or road-median positions; 5) traffic islands and roundabouts surrounded by carriageways but not designed as gardens or other formal amenity open spaces; 6) spaces below flyovers or foot bridges; and 7) planters, both fixed and movable types, placed on the previously mentioned habitats.

Trees in the following types of habitats were excluded from the survey: 1) slopes adjacent to roads; 2) along nonbuilt-up stretches of roads; 3 ) roads with restricted access to the general public; and 4) trees lying within building land lots.

The second part of the study searched for potential tree planting sites at roadsides based on a separate record form (Table 2). The same inclusions and exclusions listed previously were adopted. As a result of the tight roadside spaces, the threedimensional volume and shape of the potential planting site were emphasized. Each potential planting site was assessed according to building setback, land use, and adjacent surface type (sealed by concrete, porous pavers, or open soil). The dimensions of the plantable corridor were measured, including ground width, building awning width, awning height, site length, number of traffic lanes, and presence of adjacent car parking space (Figure 1). The boundaries of all potential planting sites were drawn on large-scale $(1: 1,000)$ maps. The findings were used to design a 5 -year planting plan.

\section{How Were the Data Collected?}

The tree survey was preceded by a reconnaissance of roadside trees in different kinds of sites in the study area to learn about tree growth, environmental impacts, and tree responses. The rather common physical and physiological constraints to tree growth were emphasized. Knowledge about the acute limitations at roadsides helped to design the field record form (Table 1).

University students in geography or ecology with field work experience were trained as research assistants. Each team with two members was assigned a work area. The study was laborintensive and time-consuming, demanding many hours of field assessments. It was important to minimize subjectivity and to calibrate judgment, especially regarding tree defects and disorders.

Training began as induction lectures to expound basic concepts in arboriculture, urban forestry, and site and tree characteristics. The lectures were abundantly illustrated with color slides of local roadside trees. Visual images were far more effective in conveying information and leaving recallable imprints. Essential visual guides to common arboricultural problems (e.g., Matheny and Clark 1994; Lonsdale 2000) and key reference books (e.g., Grey and Deneke 1986; Shigo 1991; Bradshaw et al. 1995; Miller 1996; Watson and Himelick 1997; Harris et al. 2004) were available to the assistants.

After acquiring the basic knowledge, the assistants were shown slides of tree-environment and tree defects-disorders scenarios listed in the record form and practice assessment in the classroom. Relevant concepts were explained to ascertain that data would be collected with good understanding of the underlying rationales. The helpers also learned the capabilities and limitations of the field observation and measurement methods. It was important to ensure that data collection would be a wellconsidered and fully understood exercise rather than a mechanical and prosaic routine. As an essential part of the interactive and collective learning process, they were encouraged to raise queries, discuss, and jointly fill in the record forms. A problemoriented approach was adopted to learn by questions and answers and through active discussions, participation, engagement, and interactions. The coherent group of 12 students facilitated intensive coaching and direct person-to-person communication.

On satisfactory completion of classroom training, the assistants were taken to different sites to rehearse real-world studies. Their field assessment skills were further honed by hands-on training. Most importantly, misconceptions could be promptly explained, rectified, or dispelled. The critical concern of standardization was gradually inculcated. Thereafter, they proceeded to collect live data. Initially, the author took turns accompanying different groups in the field to observe their work and provide comments and advice. They also recorded queries encountered in the survey and discussed these with the author on a regular basis. All initial data were checked for accuracy and consistence. Gradually the need for monitoring was reduced as they gained experience and confidence.

As a result of the diverse roadside tree flora in the tropical city, species identification presented challenges. Students learn to recognize common species in an urban park. Each group was equipped with reference books with tree photographs, botanical descriptions, and a dichotomous identification key (Thrower 1988; Jim 1990). Botanical references of the nearby cities of Guangzhou (Hou 1956; South China Botanical Institute 1987, 1991, 1995, 2000, 2003, 2005, 2006) and Taiwan (Lin 1960), 
Table 1. Record form for the field survey of roadside trees in urban Hong Kong.

\begin{tabular}{|c|c|c|}
\hline (A) Basic information & Type: & (E) Defects and disorders \\
\hline Group & 1. Tree pit-with grille & Surface or roots: \\
\hline Date (D) _ $(\mathrm{M})_{\ldots} \ldots(\mathrm{Y})_{-}$ & 2. Tree pit-no grille & 1. Cracked paving \\
\hline Map ref. & 3. Irregular opening & 2. Heaved paving \\
\hline \multirow[t]{2}{*}{ Street } & 4. Paved to trunk base & 3. Exposed roots \\
\hline & 5. Tree strip & 4. Girdling roots \\
\hline Tree no. & 6. Planter-movable & 5. Adventitious sprouts \\
\hline \multirow[t]{2}{*}{ Species } & 7. Planter-fixed & 6. Low soil level \\
\hline & 8. Other & 7. Compacted soil \\
\hline \multirow[t]{2}{*}{ Species code } & Protection: & Trunk: \\
\hline & 1. Level-with enclosure & 8. Leaning \\
\hline (B) Site characteristics & 2. Level-no enclosure & 9. Curved or crooked \\
\hline Building setback: & 3. Raised-with enclosure & 10. Large wound ( $>1 / 2$ diameter) \\
\hline 1. Building with setback & 4. Raised-no enclosure & 11. Cavity-good cover \\
\hline 2. Building without setback & Guard or support: & 12. Cavity-poor cover \\
\hline 3. No building & 1. Tree guard & 13. Cavity-no cover \\
\hline Land use: & 2. Permanent support & 14. Tree-tie injury \\
\hline 1. High density-commercial & 3. Temporary support & 15. At or beyond curb \\
\hline \multirow{2}{*}{$\begin{array}{l}\text { 2. High density-commercial and } \\
\text { residential }\end{array}$} & 4. Nil & 16. Vandal evidence \\
\hline & Site dimensions: & Branching: \\
\hline 3. High density-residential & Ground width __ & 17. Low branches $(<2 \mathrm{~m}[6.6 \mathrm{ft}])$ \\
\hline 4. Medium density-residential & Awning width ___ & 18. Multiple stems \\
\hline 5. Low density-residential & Awning height $\_\mathrm{m}$ & 19. V-crotch \\
\hline \multirow{2}{*}{$\begin{array}{l}\text { 6. Government, institutional, and } \\
\text { community }\end{array}$} & Soil width & 20. Embedded bark \\
\hline & Trunk-to-curb __ m & 21. Crossed branches \\
\hline 7. Industrial & Traffic lanes ___ (no.) & 22. Branch stub \\
\hline 8. Temporary use & Parking space & 23. Lost limb \\
\hline 9. Open space & & 24. Fungal stool \\
\hline 10. Hillside & (D) Tree structure & Crown or foliage: \\
\hline 11. Other & Dimensions: & 25. Sparse crown/foliage \\
\hline Adjacent surface: & Girth __ $\mathrm{cm}$ & 26. Unbalanced crown \\
\hline 1. Sealed & Height ___ $\mathrm{m}$ & 27. Stunted crown \\
\hline 2. Pervious pavers & $(\mathrm{D}=\ldots \mathrm{m})$ & 28. Leaf wilting/yellowing \\
\hline \multirow[t]{2}{*}{ 3. Open soil } & (Angle $=\ldots$ deg.) & 29. Leaf damage/deformation \\
\hline & (Observer ht. ___ m) & 30. Advertisement sign conflict \\
\hline (C) Growing space & Crown _ & Hindrance to growth: \\
\hline Roadside location: & Crown restriction: & 31. Trunk \\
\hline 1. Pavement & 1. No restriction & 32. Crown headroom \\
\hline 2. Road edge-vehicle side & 2. Property side & 33. Crown lateral room \\
\hline 3. Road edge-building side & 3. Road side & Overall rating: \\
\hline 4. Road center & 4. Both sides & 1. Excellent \\
\hline 5. Center of lane or street & & 2. Good \\
\hline 6. Terrace & & 3. Fair \\
\hline 7. Cul-de-sac & & 4. Poor \\
\hline 8. Traffic island & & 5. Dying \\
\hline \multicolumn{3}{|l|}{ 9. Incidental plot } \\
\hline \multirow[t]{2}{*}{ 10. Other } & & (F) Special features \\
\hline & & (G) Sketch \\
\hline
\end{tabular}

with similar tree flora, were consulted. For uncommon species, foliage samples were taken for identification in the laboratory. Difficult cases were handled by government or university herbarium staff.

Tree height and crown width were measured by an electronic range finder and an Abney level (using the trigonometric method). Trunk girth was measured at $1.3 \mathrm{~m}(4.3 \mathrm{ft})$ from the ground by a diameter tape. The vertical and horizontal dimensions of existing tree sites and potential planting sites were also measured. The locations of the trees and planting sites were plotted initially on paper maps and transferred to digital maps. Subsequently, an infrared beam hypsometer requiring attaching a transponder on the tree trunk was used to measure height. Recently, an improved laser beam hypsometer eliminated the need for a transponder and permitted faster and more accurate measurements. The use of a pocket computer to record data directly in digital form has been tested.

\section{How Were the Data Analyzed?}

A database structure was designed and the raw data of approximately 20,000 trees were entered into a Microsoft Excel (Microsoft, Redmond, WA, U.S.) database with the help of numeric codes to facilitate statistical analysis. The qualitative variables were converted into ordinal ranks to permit nonparametric sta- 
Table 2. Record form for the field survey of potential roadside tree planting sites in urban Hong Kong.

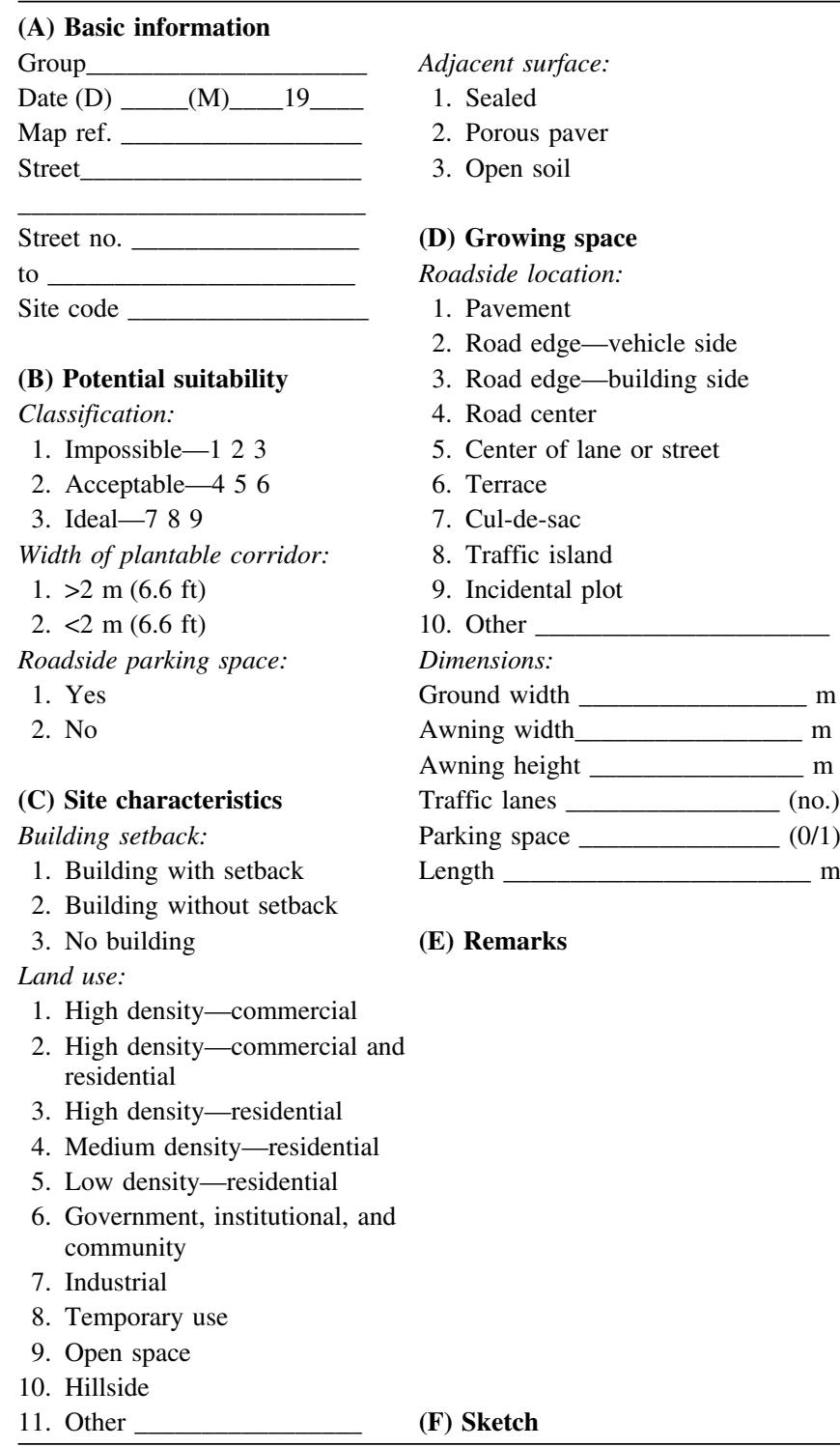

tistical analysis. Drop-down menus were designed for most data cells to facilitate data entry and minimize input errors. After thorough checking and correction, the database was read by the SPSS PC software (SPSS Inc., Chicago, IL) for statistical analysis. Tables were constructed to show the frequency of individual species with reference to tree dimensions, site conditions, and tree performance. Tables were also compiled for individual districts and streets. Pearson's correlation coefficients and $\chi^{2}$ contingent coefficients were computed, respectively, for continuous and categorical data. Principal component (factor) analysis was used to probe the multivariate relationships.

Species diversity was analyzed by indices used in community ecologic and vegetation science (Mueller-Dombois and Ellenberg 1974; Greig-Smith 1983), including species richness, Shannon-Wiener diversity index, Simpson diversity index, and Evenness index. Species similarity between tree communities, namely among districts, road categories, and land use types, was computed by the Jaccard similarity index (Seaby and Henderson

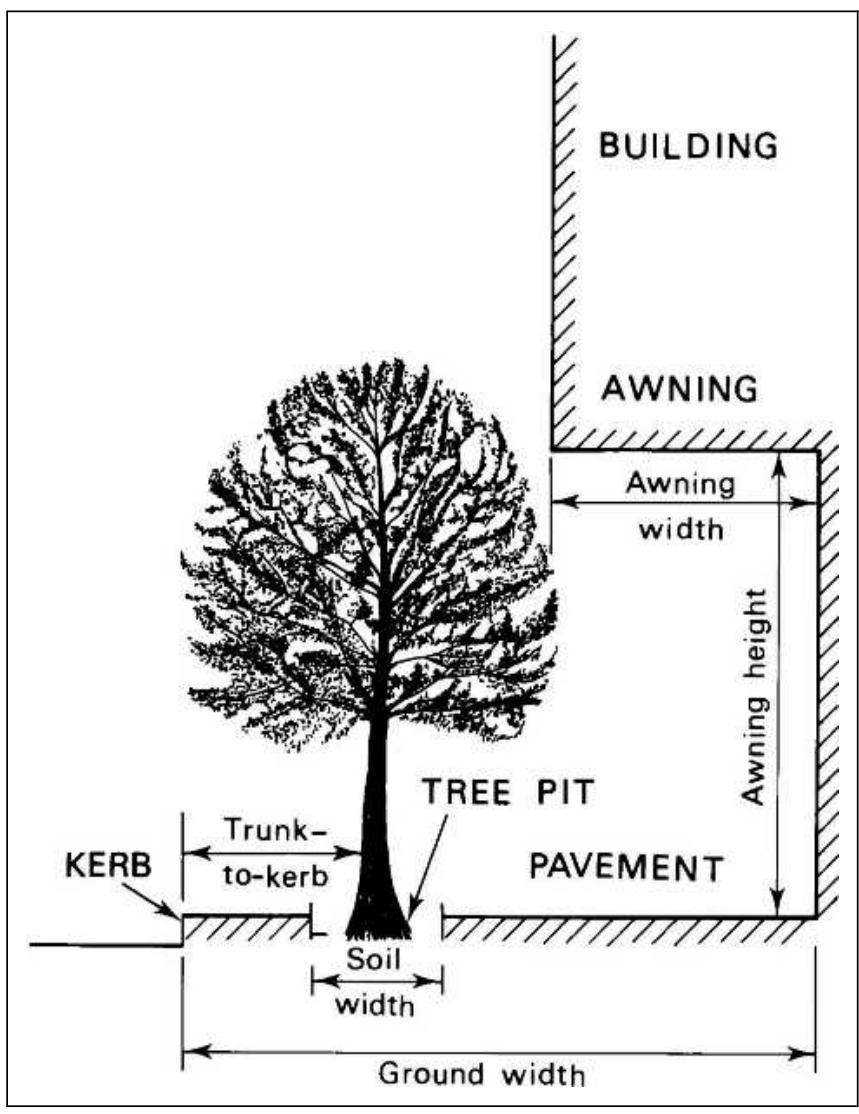

Figure 1. The definitions of five linear measurements that were made at each roadside tree site to detect the present and future physical limitations to tree growth.

2004). Four new urban tree indices to denote tree pattern in the linear habitat were developed, namely linear tree density (number of trees per kilometer of road length), linear species density (number of species per kilometer of road length), linear tree cover (aggregate tree canopy cover in square meters per kilometer of road), and linear tree biomass (aggregate crown volume in square meters per kilometer of road).

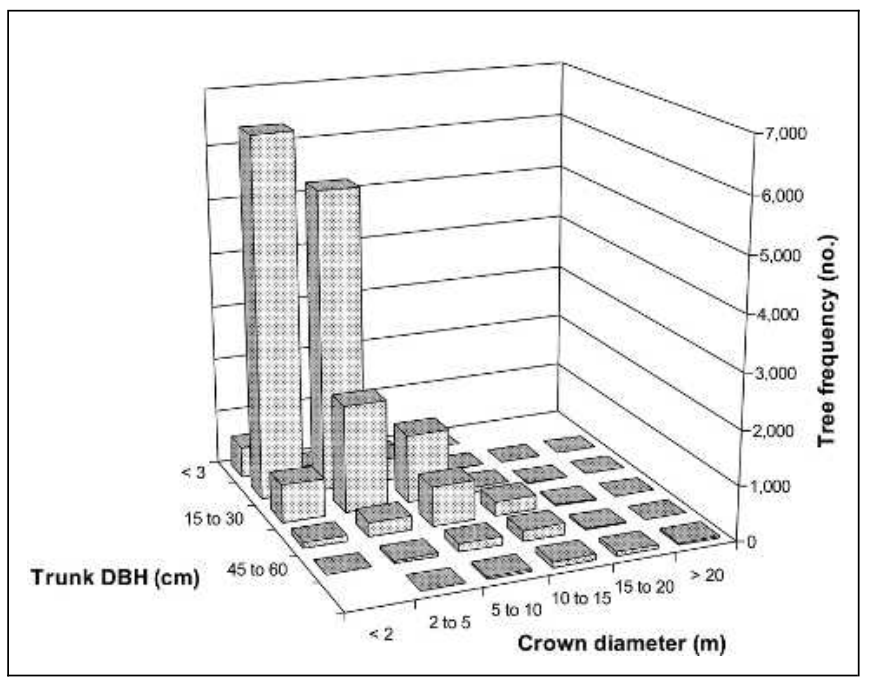

Figure 2. The frequency of roadside trees in relation to trunk diameter at breast height and crown diameter. 
The capacity of each potential planting site to hold trees was evaluated. The data on land use, general environmental quality, three-dimensional site geometry, and existing species frequencies were used to develop an elaborate site-by-site matching exercise to find the optimal species. The sites were divided into five lots for implementation over a 5-year period. Neighborhoods at present with fewer trees were given priority. A planting material demand profile was developed for advanced ordering to trigger their timely production in nurseries. A key purpose of giving advanced notification to the landscape industry was to facilitate a transformation from the deeply ingrained supply-led to a demand-led situation.

\section{Why Were Data on Individual Trees Collected?}

A comprehensive range of qualitative and quantitative information was collected (Tables 1 and 2). As far as practicable, multiple-choice answers were given on the record form to minimize subjectivity, ensure consistency, and facilitate data entry. Nonmultiple-choice answers were confined to unambiguous attributes such as street name, species names, tree number, distance and angle measurements, or simple counting. The following types of data were solicited for each target tree (Table 1):

(1) Basic information:

Research assistant group identification number,

Field survey date,

Map reference,

Street name,

Tree serial number,

Species name in Latin binomial, and

Abbreviated species code;

(2) Site characteristics:

Building setback, recording whether adjacent building was set back from the property boundary to permit tree crown expansion,

Land use, choosing one of the ten choices based on official classification, and

Adjacent surface, evaluating access of the soil around the tree to moisture, aeration, and fertilization, including the undesirable sealed surface (concrete, cement, or asphalt), less restrictive pervious pavers, and open soil;

(3) Growing space:

Roadside location, recording whether the tree was situated within the confines of the pavement, carriageway, property front, road median, street center, terrace or a cul-de-sac, traffic island, incident roadside plot, or other location,

Growing space, characterizing the microhabitat of a tree, including tree pit with or without a grille, irregular opening in the paved area, no opening (with concrete or asphalt paving up to the trunk base), planting strip, movable or fixed planter, and other types,

Protection of growing space such as level or raised edges in relation to the surrounding ground surface and the presence or absence of enclosure,

Guards or support such as tree guard, permanent or temporary tree stake or a similar structure, or no support, and

Site dimension, recording the linear horizontal or vertical measurements shown in Figure 1, the number of traffic lanes perpendicular to the tree, and whether on-street car parking space was available adjacent to the tree;

(4) Tree structure:

Trunk girth, measuring at $1.3 \mathrm{~m}(4.3 \mathrm{ft})$ from the ground; if branching height was lower than $1.3 \mathrm{~m}(4.3 \mathrm{ft})$, the girth was measured immediately below the first branch; for multiple stemmed trees, the girths of the trunks were summed,

Tree height using the trigonometric approach,

Crown diameter measured by an electronic range finder; for evidently asymmetric crowns, the average of the maximum and minimum diameters was recorded, and

Gap between crown and adjacent structure; if it was less than three-fourths of the crown diameter, the location of crown restriction (property, carriageway side, or both) was recorded;

(5) Defects and disorders:

Detailed evaluation of individual trees was made according to 33 common physical and physiological ailments placed under five groups, and

Overall rating of tree performance, classifying a tree according to a 5-point scale (excellent, good, fair, poor, and dying);

(6) Special features/remarks:

Any unusual observation not solicited in the record form was recorded; and

(7) Sketch:

Where necessary, a simple sketch of the tree and its immediate environs was drawn to explain unusual observations.

\section{Why Were Data on Potential Planting Sites Collected?}

The search for potential planting sites followed Table 2. Some attributes were similar to the tree survey, and only those unique to the site survey would be explained:

(1) Basic information:

Street number, referring to the starting and end point of the potential planting site, and

Site code, a serial identification number;

(2) Potential suitability:

Site classification aided by a synoptic diagram of different roadside configuration vis-à-vis tree planting and growth potential,

Width of the plantable corridor, which should be greater than $2 \mathrm{~m}(6.6 \mathrm{ft})$, and

Roadside parking space, indicating opportunities to insert trees outside the curb line between the ends of parking spaces, where awning and other restrictions often did not allow planting inside the curb line; it could provide more room for tree crowns to expand above the carriageway without causing unacceptable traffic or sightline obstructions;

(3) Site characteristics:

The same attributes for the tree survey were recorded;

(4) Growing space:

Two attributes, namely roadside location and site dimensions, were recorded using the same format as the tree survey; 
(5) Underground constraints:

Undertaken by government tree management staff in conjunction with other departments and utility companies when the sites were actually used for tree planting;

(6) Remarks:

Unusual features not solicited in the previously mentioned attributes were recorded; and

(7) Sketch:

Where it helped to illustrate special observation, a sketch would be drawn.

\section{RESULTS AND DISCUSSION Advantages and Disadvantages of the Data Collection Approach}

The data collection approach has the advantage of covering all target trees in the study area in a census. It could avoid possible sampling errors and problems of representation of different population strata (Jaenson et al. 1992; Alvarez et al. 2005). The data were either quantitative or could be converted into ordinal ranks to facilitate statistical analysis. Plotting the locations of trees and potential planting sites on digital maps permitted spatial analysis of the distribution pattern. Detailed information covered not just individual trees, but also planting sites and the immediate environs. Information on physical constraints to tree growth, including present and future restrictions, and symptoms of main tree defects and disorders could help tree managers design the tree maintenance strategy and program.

The information on potential planting sites allowed advanced planning to improve the geographic spread, species diversity, and landscape contribution of roadside trees in different districts. The implementation of the synoptic planting plan is firmly based on in-depth understanding of ground truths at the potential planting sites. The recommended species could take into consideration existing species makeup and projection of the landscape, amenity, and environmental and ecologic needs of the area in the future. Different neighborhoods could be allotted a certain signature species to accentuate local landscape identity.

The findings could assist tree managers to identify the strengths and weaknesses of the existing urban tree program and design the future management plan according to the identified problems, priorities, and resource envelope. More importantly, the systematic data analysis could yield useful hints to avoid past pitfalls in site preparation, species selection, and tree care; reinforce the good choices and practices; and find new or alternative ways to tighten and enhance the urban tree management package. Overall, the method is comprehensive in scope and depth to serve multiple purposes. The tree survey could be expanded to include a questionnaire survey of citizens' preferences (Schroeder et al. 2003) and attitudes (Schroeder et al. 2006) so that the urban forestry program could be adjusted to the community's wishes. Opinions of professional urban foresters could also be explored to identify institutional factors and predictors of better tree performance and management (D'Amato et al. 2002; Lewis and Boulahanis 2008).

The approach has its disadvantages. It demanded much labor input and the corollary of a sizeable financial compensation to tree surveyors over an extended period. It required assistants with good knowledge and skills of urban forestry and arboriculture and competence in species identification. It necessitated many hours of laborious evaluation of trees and tree sites in the field, filling in a detailed record form and inputting the data into a computer database. Over an extended period, experienced team members would leave and new members had to be recruited and trained.

For attributes involving open-ended (nonmultiple choices) answers, inconsistency in judgment by different surveyors may lower data quality. The possible sources of errors are registration of wrong records in the field and erroneous judgment, measurements, and species identification. Additional errors could also be introduced at the data entry stage.

The database could be stored centrally in a network server with access rights assigned to tree managers at the central and district levels. Data collected in this manner have a certain life span. Updating could be coordinated at the management level. Each district's tree manager will modify the database on a monthly basis to record tree felling, planting, major maintenance operations, changes in tree performance, and alterations in planting site conditions. A continually and diligently updated database could maintain its usefulness for many years. It is recommended that the tree survey should be repeated once every 10 years to overhaul the information, which will offer chances to introduce new tree survey methods and attributes associated with the latest research findings and practices.

The positions of the individual trees were plotted on maps with the help of the AutoCAD program (Autodesk Inc., San Rafael, CA). Because global positioning satellite (GPS) programs are now widely available at a reasonable cost, the technology could be integrated into the field survey methodology to record the locations of trees with reference to a local coordinate system. The spatial data could be transferred to a GIS program to facilitate research and planning for tree management. Once digitized in a GIS setting, the spatial data of trees and potential planting sites could be efficiently analyzed and depicted. The integration of GIS and GPS technologies in urban tree surveys was initiated in the late 1990s (Widdicombe and Carlisle 1999) with recent emergence of some proprietary software products.

Photographic records of individual trees or tree groups taken at different times, using the repeat photography method, could yield useful information on changes in urban vegetation. Sequential aerial photographs could trace the changes in urban tree cover in response to urbanization effects (Jim 1989; Nowak 1993).

\section{Species Composition and Diversity}

The census recorded approximately 20,000 trees from 149 different species. Considering the size of the study area and the human population, the number of street trees was rather limited. Comparison with other south Chinese cities such as Guangzhou and Taipei indicates the lack of street trees in Hong Kong (Table 3 ). It signified an improvement in comparison with approximately 10,000 trees found in the 1985 survey. The severe constraints to roadside trees in the cramped urban environment were reflected by the survey results. The large number of species represented a surprisingly high botanical diversity uncommonly found in other city streets. The 149 species have been classified into five groups with respect to frequencies (Table 4).

The roadside trees were dominated by a small cohort of common species with the top eight taking up 50\% and the top 14 comprising approximately two-thirds of the total stock. A similar pattern of dominance was found in Guangzhou and Taipei (Table 3 ). Only the top 17 species had individual frequencies exceeding 
Table 3. Frequency of occurrence of the top $\mathbf{2 0}$ common street trees in three south Chinese cities.

\begin{tabular}{|c|c|c|c|c|c|c|c|c|}
\hline \multicolumn{2}{|c|}{ Rank } & Species $^{z}$ & Family & Growth form ${ }^{\mathrm{y}}$ & Final height ${ }^{\mathrm{x}}$ & Frequency & Percent & Cumulative percent \\
\hline \multicolumn{9}{|c|}{ (a) Hong Kong (total 19,154 trees) } \\
\hline 1 & & Aleurites moluccana & Euphorbiaceae & BLE & Medium & 2,474 & 12.92 & 12.92 \\
\hline 2 & & Melaleuca quinquenervia & Myrtaceae & BLE & Medium & 1,444 & 7.54 & 20.46 \\
\hline 3 & & Phoenix roebelenii & Arecaceae & Palm & Small & 1,337 & 6.98 & 27.44 \\
\hline 4 & & Livistona chinensis & Arecaceae & Palm & Medium & 1,325 & 6.92 & 34.36 \\
\hline 5 & & Caryota ochlandra & Arecaceae & Palm & Medium & 1,018 & 5.31 & 39.67 \\
\hline 6 & & Archontophoenix alexandrae & Arecaceae & Palm & Medium & 688 & 3.59 & 43.26 \\
\hline 7 & \multirow[t]{4}{*}{ \# } & Bombax malabaricum & Bombacaceae & BLD & Large & 648 & 3.38 & 46.65 \\
\hline 8 & & Delonix regia & Caesalpiniaceae & BLD & Large & 647 & 3.38 & 50.02 \\
\hline 9 & & Cassia siamea & Caesalpiniaceae & BLE & Large & 573 & 2.99 & 53.02 \\
\hline 10 & & Cassia surattensis & Caesalpiniaceae & BLE & Small & 520 & 2.71 & 55.73 \\
\hline 11 & \multirow[t]{3}{*}{ \# } & Ficus microcarpa & Moraceae & BLE & Large & 476 & 2.49 & 58.22 \\
\hline 12 & & Washingtonia robusta & Arecaceae & Palm & Medium & 473 & 2.47 & 60.69 \\
\hline 13 & & Ficus benjamina & Moraceae & BLE & Large & 445 & 2.32 & 63.01 \\
\hline 14 & \multirow[t]{4}{*}{ \# } & Hibiscus tiliaceus & Malvaceae & BLE & Medium & 437 & 2.28 & 65.29 \\
\hline 15 & & Crateva unilocularis & Capparidaceae & BLD & Medium & 429 & 2.24 & 67.53 \\
\hline 16 & & Thevetia peruviana & Apocynaceae & BLE & Small & 421 & 2.20 & 69.73 \\
\hline 17 & & Acacia confusa & Mimosaceae & BLE & Medium & 415 & 2.17 & 71.89 \\
\hline 18 & \multirow[t]{2}{*}{ \# } & Bauhinia blakeana & Caesalpiniaceae & BLE & Small & 382 & 1.99 & 73.89 \\
\hline 19 & & Roystonea regia & Arecaceae & Palm & Large & 363 & 1.90 & 75.78 \\
\hline \multirow[t]{2}{*}{20} & \multirow[t]{2}{*}{$\#$} & Albizia lebbeck & Mimosaceae & BLD & Large & 312 & 1.63 & 77.41 \\
\hline & & & & & & 14,827 & 77.41 & \\
\hline \multicolumn{9}{|c|}{ (b) Taipei (total 37,612 trees) } \\
\hline 1 & \# & Cinnamomum camphora & Lauraceae & BLE & Large & 6,792 & 18.06 & 18.06 \\
\hline 2 & \# & Ficus microcarpa & Moraceae & BLE & Large & 5,873 & 15.61 & 33.67 \\
\hline 3 & \multirow[t]{2}{*}{ \# } & Koelreuteria elegans & Sapindaceae & BLD & Small & 3,675 & 9.77 & 43.44 \\
\hline 4 & & Melaleuca quinquenervia & Myrtaceae & BLE & Medium & 2,122 & 5.64 & 49.09 \\
\hline 5 & \# & Bischofia javanica & Euphorbiaceae & BLD & Large & 2,042 & 5.43 & 54.51 \\
\hline 6 & \multirow[t]{2}{*}{$\#$} & Liquidambar formosana & Hamamelidaceae & BLD & Large & 1,907 & 5.07 & 59.58 \\
\hline 7 & & Roystonea regia & Arecaceae & Palm & Large & 1,767 & 4.70 & 64.28 \\
\hline 8 & \multirow[t]{12}{*}{ \# } & Ulmus parvifolia & Ulmaceae & BLD & Small & 1,208 & 3.21 & 67.49 \\
\hline 9 & & Bombox malabaricum & Bombacaceae & BLD & Large & 1,110 & 2.95 & 70.45 \\
\hline 10 & & Ficus religiosa & Moraceae & BLD & Large & 1,065 & 2.83 & 73.28 \\
\hline 11 & & Peltophorum pterocarpum & Caesalpiniaceae & BLD & Medium & 764 & 2.03 & 75.31 \\
\hline 12 & & Lagerstroemia speciosa & Lythraceae & BLD & Small & 751 & 2.00 & 77.31 \\
\hline 13 & & Alstonia schloaris & Apocynaceae & BLE & Medium & 739 & 1.96 & 79.27 \\
\hline 14 & & Terminalia mantalyi & Combretaceae & BLD & Medium & 562 & 1.49 & 80.76 \\
\hline 15 & & Ficus elastica & Moraceae & BLE & Large & 455 & 1.21 & 81.97 \\
\hline 16 & & Erythrina indica & Fabaceae & BLD & Medium & 418 & 1.11 & 83.09 \\
\hline 17 & & Pongamia pinnata & Fabaceae & BLD & Medium & 309 & 0.82 & 83.91 \\
\hline 18 & & Mangifera indica & Anacardiaceae & BLE & Large & 259 & 0.69 & 84.60 \\
\hline 19 & & Phoenix roebelenii & Arecaceae & Palm & Small & 235 & 0.62 & 85.22 \\
\hline \multirow[t]{2}{*}{20} & \multirow[t]{2}{*}{ \# } & Pistacia chinensis & Anacardiaceae & BLD & Medium & 188 & 0.50 & 85.72 \\
\hline & & & & & & 32,241 & 85.72 & \\
\hline \multicolumn{9}{|c|}{ (c) Guangzhou (total 46,930 trees) } \\
\hline 1 & \# & Ficus virens & Moraceae & BLD & Large & 8,072 & 17.20 & 17.20 \\
\hline 2 & & Bauhinia blakeana & Caesalpiniaceae & BLE & Small & 4,244 & 9.04 & 26.24 \\
\hline 3 & & Aleurites moluccana & Euphorbiaceae & BLE & Medium & 3,485 & 7.43 & 33.67 \\
\hline 4 & $\#$ & Ficus microcarpa & Moraceae & BLE & Large & 3,296 & 7.02 & 40.69 \\
\hline 5 & $\#$ & Bauhinia variegata & Caesalpiniaceae & BLD & Small & 3,094 & 6.59 & 47.29 \\
\hline 6 & & Chukrasia tabularis & Meliaceae & BLE & Large & 2,880 & 6.14 & 53.42 \\
\hline 7 & & Melaleuca quinquenervia & Myrtaceae & BLE & Medium & 2,678 & 5.71 & 59.13 \\
\hline 8 & \# & Bombax malabaricum & Bombacaceae & BLD & Large & 2,253 & 4.80 & 63.93 \\
\hline 9 & & Casuarina equisetifolia & Caesalpiniaceae & BLE & Large & 2,016 & 4.30 & 68.23 \\
\hline 10 & & Mangifera indica & Anacardiaceae & BLE & Large & 1,260 & 2.68 & 70.91 \\
\hline 11 & & Acacia auriculiformis & Mimosaceae & BLE & Medium & 1,177 & 2.51 & 73.42 \\
\hline 12 & & Michelia alba & Magnoliaceae & BLE & Large & 1,087 & 2.32 & 75.73 \\
\hline 13 & & Syzygium grande & Myrtaceae & BLE & Medium & 932 & 1.99 & 77.72 \\
\hline
\end{tabular}


Table 3. Frequency of occurrence of the top 20 common street trees in three south Chinese cities. (continued)

\begin{tabular}{|c|c|c|c|c|c|c|c|c|}
\hline Rank & & Species $^{z}$ & Family & Growth form ${ }^{\mathrm{y}}$ & Final height ${ }^{\mathrm{x}}$ & Frequency & Percent & Cumulative percent \\
\hline 14 & \multirow{8}{*}{$\#$} & Khaya senegalensis & Meliaceae & BLE & Large & 817 & 1.74 & 79.46 \\
\hline 15 & & Cleidiocarpon cavalieri & Euphorbiaceae & BLE & Large & 662 & 1.41 & 80.87 \\
\hline 16 & & Ficus altissima & Moraceae & BLE & Large & 595 & 1.27 & 82.14 \\
\hline 17 & & Livistona chinensis & Arecaceae & Palm & Medium & 375 & 0.80 & 82.94 \\
\hline 18 & & Lagerstroemia indica & Lythraceae & BLD & Small & 354 & 0.75 & 83.69 \\
\hline 19 & & Mangifera persiciformis & Anacardiaceae & BLE & Small & 353 & 0.75 & 84.44 \\
\hline \multirow[t]{2}{*}{20} & & Cassia surattensis & Caesalpiniaceae & BLE & Small & 352 & 0.75 & 85.19 \\
\hline & & & & & & 39,982 & 85.19 & \\
\hline
\end{tabular}

$\mathrm{z}_{\#}=$ the species is native to the city in question.

${ }^{\mathrm{y}}$ Growth form is classified into: BLE $=$ broadleaf evergreen; BLD $=$ broadleaf deciduous and palm; no conifers are found in the top 20 common species.

${ }^{\mathrm{x}}$ Final tree height is classified into: small for less than $9 \mathrm{~m}(29.7 \mathrm{ft})$, medium for 9 to $18 \mathrm{~m}(29.7$ to $59.4 \mathrm{ft})$, and large for greater than $18 \mathrm{~m}(59.4 \mathrm{ft})$.

$2 \%$. Among the less common species, some were cultivated in the past and yet remained rare, and some were only recently used at roadsides in the study area. A small number was inherited from pre-existing woodlands or gardens. Overall, the tree population was mainly represented by a limited range of common species, but the species diversity was notably enriched by many uncommon species. Tree selection for urban planting in the future could explore the large pool of uncommon species.

By growth form, the domination by broad-leaved trees versus other growth forms was evident (Table 5). Evergreen trees contributed $83.4 \%$, and the overall distribution of growth form was consistent with the regional humid subtropical climate and south China flora. By geographic origin, some $82 \%$ of the trees and $72.5 \%$ of the species were exotic; such a heavy reliance on aliens was not uncommon in other tropical cities (Table 3). Only a few native species managed to become common. Endowment in terms of tree count and species diversity varied notably between districts (Table 6). Tree density also differed a lot among districts. The tree planting plan could bring some redress to the imbalance.

\section{Tree Growth and Environmental Conditions}

The stock was dominated by small trees (with less than $15 \mathrm{~cm} \mathrm{[6}$ in] diameter at breast height [dbh], less than $5 \mathrm{~m}$ [16.5 ft] height, and less than $5 \mathrm{~m}$ [16.5 ft] crown spread), which took up twothirds of the roadside trees (Figure 2). The youthful state reflected the recent spate of assiduous planting efforts. Only approximately $10 \%$ of the trees were large (30 to $60 \mathrm{~cm}$ [12 to 24 in] dbh) and exceptionally large (greater than $60 \mathrm{~cm} \mathrm{[24} \mathrm{in]} \mathrm{dbh).}$ Such a size bias indicated that many trees failed to reach their biologic maximum dimensions as a result of the inordinately poor roadside environment and widespread mistreatment and that not many species with large potential size were planted in the past.

The study has identified some outstanding specimens, the champion trees, for special care and protection. Many of these previous trees were inherited from the past when the tree growth environment was more conducive to good performance. The survey finds drastic deterioration in their growth site both in the soil and the aboveground conditions. They call for dedicated measures to improve site conditions to ensure that the valuable remnant trees could persist as natural-cum-cultural heritage of the community (Jim 2005). The large specimens in good condition, constituting the champion trees, should be added to the champion tree collection.

By growth space, grass strips situated either adjacent to pavements or at central divider locations were the most common
(51.6\%). They provided generous above- and belowground growing spaces for tree expansion. Tree pits were the second popular growth space holding $32.8 \%$ of the trees; approximately two-thirds had a grille mainly installed in recent years. Some $11.5 \%$ of the trees were accommodated in planters with approximately three-fifths fixed and the rest movable. Approximately $2.8 \%$ of the trees were restricted in irregular openings or with concrete paved to their trunk base. Many exceptionally large trees were found in limited growth spaces attributable mainly to land-use changes. Large and medium trees were found mainly in tree pits or grassed strips. Small trees were heavily concentrated in grassed strips.

Trees in high-density urban areas commonly experience the grave shortage of growth space both below and above the ground (Attorre et al. 2000). Tree growth in Hong Kong was widely hampered by various physical and physiological obstacles. Most trees were confined to narrow tree pits or planting strips, and the recently planted ones had more soil rooms. Off-pavement sites were better off with wider grass strips. Some trees were beset by a mismatch between site and final tree dimensions. Because most trees were planted at places without building awnings, the lateral and vertical limitations resulting from this constraint were not common. Physical restrictions to tree growth were common at roadside habitats. It was therefore understandable, if not expected, that the street-tree population is so small. High-quality sites were uncommon, and most trees were planted under suboptimal conditions. The temporary nature of some sites resulting from frequent road and building works imposed additional constraints.

The detailed tree survey data that include species and tree dimensions could be used to assess the environmental and ecologic benefits of the urban forest. The development of the CITYgreen software (American Forests, Washington, DC) expands the GIS capability to the synoptic evaluation of urban tree canopy cover and associated environmental benefits (Dwyer and Miller 1999; American Forests 2004). A similar method was developed to evaluate the spatial pattern of urban tree cover in Munich and to assess its environmental benefits (Pauleit and Duhme 2000).

The survey data could serve as inputs into the Urban Forest Effects (UFORE) model to provide detailed assessment of the environmental benefits (Nowak and Crane 2000; Nowak et al. 2000). Other evaluation and computation methods have also been applied to estimate the environmental benefits of urban forests (e.g., Maco et al. 2004). The ecosystem services could be translated into economic value and monetary units to facilitate 
Table 4. Roadside tree composition in Hong Kong according to five frequency groups.

\begin{tabular}{|c|c|c|c|c|c|}
\hline \multirow[b]{2}{*}{ Frequency group } & \multirow[b]{2}{*}{ Frequency range } & \multicolumn{2}{|c|}{ Number of trees } & \multicolumn{2}{|c|}{ Number of species } \\
\hline & & Count & Percent & Count & Percent \\
\hline Dominant & Greater than 500 & 10,674 & 55.7 & 10 & 6.7 \\
\hline Abundant & 150 to 500 & 5,121 & 26.7 & 14 & 9.4 \\
\hline Frequent & 50 to 149 & 2,249 & 11.7 & 23 & 15.4 \\
\hline Occasional & 10 to 49 & 856 & 4.5 & 33 & 22.1 \\
\hline \multirow[t]{2}{*}{ Rare } & Less than 10 & 254 & 1.3 & 69 & 46.3 \\
\hline & Total & 19,154 & 100 & 149 & 100 \\
\hline
\end{tabular}

understanding of tree values (McPherson et al. 1997; Tyrväinen and Miettinen 2000; Jim and Chen, in press). Benefit-cost analysis of individual species could provide hints to selection of species to maximize their benefits (McPherson 2003). Such findings could provide strong justifications to preserve tree budgets and to compete with other claims for municipal funding.

\section{Potential Planting Sites}

A total of 1,094 potential planting sites with a maximum capacity for 12,063 trees were visually identified in the survey. All plantable locations have been marked on 1:1,000 large-scale maps. The sites were unevenly distributed in districts and regions with Kowloon East taking up 49\%, Hong Kong East 22.7\%, Hong Kong West $14.8 \%$, and Kowloon West $13.5 \%$. For the study area as a whole with at present 509 streets with trees, a further 389 more could be greened.

Most potential planting sites were small, each with room for less than 13 trees, including many that could accommodate only a few. Only 138 sites could hold more than 20 trees, and only six were large enough for more than 60 . On average, each site could encompass 11 trees and each street 31 trees. Thus, the sites were both small and scattered. By dimensions, most sites were shorter than $100 \mathrm{~m}(330 \mathrm{ft})$ and narrower than $5 \mathrm{~m}(16.5 \mathrm{ft})$. Some $89 \%$ of the sites were free from awnings, and the same proportion was situated on pavements. Most off-pavement sites had already been enlisted for planting. The spread of sites among different land uses was very uneven. In addition to using field survey, aerial photographs or satellite imageries could offer an additional tool to identify potential planting sites in cities (Wu et al. 2008). However, ground truths with pertinent bearing on tree growth could not be gleaned; hence, at the implementation stage, field evaluation of the planting site would still be necessary.

The actual number of plantable trees could be significantly reduced as a result of various above- and belowground constraints. In practice, at the most, approximately $70 \%$ of the sites could actually be used. It was anticipated that these potential sites would be used up soon. Thereafter, plantable sites would have to come from new development and urban renewal areas. The findings demanded a concerted effort to change the town plan if urban roadside greening were to continue in the future. A joint effort between the government and developers, following clearly defined objectives, would be needed to generate additional planting sites in the long term (Jim 2004b).

The poor performance of many trees, particularly at roadsides, calls for an overhaul of the tree establishment practice. The survey data provided telltale information on soil characteristics at the existing tree sites and hints at soil qualities at the potential planting sites. It is particularly important to assess soil quality and soil volume available for root growth, because it has been identified as a serious constraint on tree establishment and

Table 5. Distribution of roadside trees by growth form in ten urban districts of Hong Kong.

\begin{tabular}{|c|c|c|c|c|c|c|c|c|c|c|}
\hline \multirow[b]{2}{*}{ District } & \multicolumn{2}{|c|}{ Broadleaf evergreen } & \multicolumn{2}{|c|}{ Broadleaf deciduous } & \multicolumn{2}{|c|}{ Conifer and related } & \multicolumn{2}{|c|}{ Palm and palm-like } & \multicolumn{2}{|l|}{ Total } \\
\hline & Count & Percent & Count & Percent & Count & Percent & Count & Percent & Count & Percent \\
\hline \multicolumn{11}{|l|}{ Hong Kong West } \\
\hline Southern & 717 & 53.7 & 350 & 26.2 & 34 & 2.5 & 233 & 17.5 & 1,334 & 100 \\
\hline Subtotal & 1,318 & 49.6 & 583 & 22.0 & 58 & 2.2 & 696 & 26.2 & 2,655 & 100 \\
\hline \multicolumn{11}{|l|}{ Hong Kong East } \\
\hline Subtotal & 2,534 & 53.0 & 854 & 17.9 & 46 & 1.0 & 1,350 & 28.2 & 4,784 & 100 \\
\hline \multicolumn{11}{|l|}{ Kowloon West } \\
\hline Yau-Tsim & 1,049 & 55.3 & 267 & 14.1 & 20 & 1.1 & 560 & 29.5 & 1,896 & 100 \\
\hline Mong Kok & 161 & 40.0 & 53 & 13.2 & 6 & 1.5 & 183 & 45.4 & 403 & 100 \\
\hline Sham Shui Po & 906 & 52.0 & 399 & 22.9 & 2 & 0.1 & 435 & 25.0 & 1,742 & 100 \\
\hline Subtotal & 2,116 & 52.4 & 719 & 17.8 & 28 & 0.7 & 1,178 & 29.2 & 4,041 & 100 \\
\hline Subtotal & 4,137 & 53.9 & 1,020 & 13.3 & 144 & 1.9 & 2,373 & 30.9 & 7,674 & 100 \\
\hline Total & 10,105 & 52.8 & 3,176 & 16.6 & 276 & 1.4 & 5,597 & 29.2 & 19,154 & 100 \\
\hline
\end{tabular}


Table 6. Frequency, diversity, and density characteristics of roadside trees in ten urban districts of Hong Kong.

\begin{tabular}{|c|c|c|c|c|c|c|c|c|}
\hline \multirow[b]{2}{*}{ District } & \multicolumn{2}{|c|}{ Tree frequency } & \multicolumn{2}{|c|}{ Species richness } & \multicolumn{2}{|c|}{ Species diversity } & \multirow{2}{*}{$\frac{\text { Tree density }}{\text { trees } / \mathrm{km}^{2}}$} & \multirow{2}{*}{$\begin{array}{l}\text { Street with trees } \\
\text { No. }\end{array}$} \\
\hline & Count & Percent & Count & Percent ${ }^{\mathrm{z}}$ & Index ${ }^{y}$ & Rank & & \\
\hline \multicolumn{9}{|l|}{ Hong Kong West } \\
\hline Southern & 1334 & 7.0 & 66 & 44.3 & 4.9 & 3 & 34 & 55 \\
\hline \multicolumn{9}{|l|}{ Hong Kong East } \\
\hline Eastern & 2730 & 14.3 & 63 & 42.3 & 2.3 & 9 & 147 & 59 \\
\hline Yau-Tsim & 1896 & 9.9 & 57 & 38.3 & 3.0 & 5 & 487 & 44 \\
\hline Mong Kok & 403 & 2.1 & 39 & 26.2 & 9.7 & 1 & 255 & 24 \\
\hline Sham Shui Po & 1742 & 9.1 & 52 & 34.9 & 3.0 & 6 & 204 & 41 \\
\hline \multicolumn{9}{|l|}{ Kowloon East } \\
\hline Kowloon City & 2603 & 13.6 & 67 & 45.0 & 2.6 & 8 & 268 & 86 \\
\hline Wong Tai Sin & 1701 & 8.9 & 48 & 32.2 & 2.8 & 7 & 182 & 39 \\
\hline
\end{tabular}

${ }^{\mathrm{z}}$ Species richness $(\%)=($ species count $/ 149) \times 100 \%$; total number of species equals 149 .

${ }^{\mathrm{y}}$ Species diversity index $=($ species count/tree count $) \times 100$.

growth in compact cities (Jim 1998c; Pauleit et al. 2002). The need to ameliorate impervious soil sealing and soil compaction problems before tree planting cannot be more emphatically stressed (Jim 1998b; Herz et al. 2003). The potential planting site survey found some locations that could accommodate large tree pits, tree strips, or soil corridors to improve long-term tree growth (Bühler et al. 2007). The need for soil replacement and soil improvement by amendments could also be assessed with the help of the survey data. Instead of sticking to the standard and anachronistic tree pit design that traps newly planted trees in a tiny soil volume of $1 \mathrm{~m}^{3}\left(35 \mathrm{ft}^{3}\right)$, it is necessary to provide custom-designed solutions to individual planting sites to tackle a chronic problem in local tree growth.

\section{Species Recommendation and Planting Plan}

Information on the recommended species was compiled to assist tree selection. The most important consideration was finding an optimal match between site characteristics and final tree dimensions. The width of the plantable site was the primary criterion in species selection. Other site attributes included building setback, awning, roadside location, and land use. For the species, attainable height (exceptionally large, greater than $15 \mathrm{~m}$ [49.5

Table 7. An extract of the 5-year roadside tree planting plan showing the assignment of suitable number of trees and species to individual potential planting sites identified in the course of the tree census.

\begin{tabular}{|c|c|c|c|c|c|c|c|c|c|c|}
\hline $\begin{array}{l}\text { Serial } \\
\text { number }\end{array}$ & Map reference & District & Street & $\begin{array}{l}\text { Site } \\
\text { code }\end{array}$ & $\begin{array}{l}\text { Land } \\
\text { use }\end{array}$ & $\begin{array}{l}\text { Roadside } \\
\text { location }\end{array}$ & $\begin{array}{l}\text { Plantable } \\
\text { width (m) }\end{array}$ & $\begin{array}{l}\text { Building } \\
\text { setback }\end{array}$ & $\begin{array}{l}\text { Plantable } \\
\text { tree (no.) }\end{array}$ & Species \\
\hline 1 & $11 \mathrm{NE} 01 \mathrm{~A}$ & WTS & Tsz Wan Shan Rd & 1 & 3 & 1 & 4.5 & 2 & 6 & Callistemon rigidus \\
\hline 2 & 11NE01B & WTS & Tsz Wan Shan Rd & 1 & 2 & 1 & 3.8 & 2 & 30 & Callistemon rigidus \\
\hline 3 & $11 \mathrm{NE} 01 \mathrm{~B}$ & WTS & Tsz Wan Shan Rd & 2 & 10 & 1 & 4.8 & 3 & 2 & Spathodea campanulata \\
\hline 4 & $11 \mathrm{NE} 01 \mathrm{C}$ & WTS & Chuk Yuen Rd & 1 & 3 & 1 & 3.0 & 2 & 16 & Syzygium hancei \\
\hline 5 & $11 \mathrm{NE} 01 \mathrm{C}$ & WTS & Chuk Yuen Rd & 2 & 10 & 1 & 2.9 & 3 & 18 & Jacaranda mimosifolia \\
\hline 6 & $11 \mathrm{NE} 01 \mathrm{C}$ & WTS & Chuk Yuen Rd & 3 & 2 & 1 & 3.2 & 2 & 13 & Syzygium hancei \\
\hline 7 & $11 \mathrm{NE} 01 \mathrm{C}$ & WTS & Chuk Yuen Rd & 4 & 10 & 1 & 3.1 & 3 & 19 & Jacaranda mimosifolia \\
\hline 8 & $11 \mathrm{NE} 01 \mathrm{C}$ & WTS & Choi Chuk St & 5 & 10 & 1 & 3.0 & 3 & 14 & Podocarpus nagi \\
\hline 9 & $11 \mathrm{NE} 01 \mathrm{C}$ & WTS & Choi Chuk St & 6 & 2 & 1 & 3.0 & 1 & 12 & Brachychiton acerifolius \\
\hline 10 & $11 \mathrm{NE} 01 \mathrm{C}$ & WTS & Wing Chuk St & 7 & 10 & 1 & 2.8 & 3 & 13 & Albizia lebbeck \\
\hline 11 & $11 \mathrm{NE} 01 \mathrm{C}$ & WTS & Wing Chuk St & 8 & 10 & 1 & 3.2 & 3 & 13 & Pterocarya stenoptera \\
\hline 12 & $11 \mathrm{NE} 01 \mathrm{C}$ & WTS & Chui Chuk Lane & 9 & 10 & 1 & 2.8 & 3 & 16 & Khaya senegalensis \\
\hline 13 & $11 \mathrm{NE} 01 \mathrm{C}$ & WTS & Chui Chuk Lane & 10 & 10 & 1 & 2.8 & 3 & 14 & Koelreuteria bipinnata \\
\hline 14 & $11 \mathrm{NE} 01 \mathrm{C}$ & WTS & Chui Chuk Lane & 11 & 10 & 1 & 2.8 & 3 & 23 & Khaya senegalensis \\
\hline 15 & $11 \mathrm{NE} 01 \mathrm{C}$ & WTS & Chuk Yuen Rd & 12 & 10 & 1 & 3.3 & 3 & 14 & Jacaranda mimosifolia \\
\hline 16 & $11 \mathrm{NE} 01 \mathrm{C}$ & WTS & Chuk Yuen Rd & 13 & 10 & 1 & 3.3 & 3 & 9 & Bischofia javanica \\
\hline 17 & $11 \mathrm{NE} 01 \mathrm{C}$ & WTS & Chuk Yuen Rd & 14 & 10 & 1 & 3.2 & 3 & 16 & Jacaranda mimosifolia \\
\hline 18 & $11 \mathrm{NE} 01 \mathrm{C}$ & WTS & Shatin Pass Rd & 15 & 10 & 1 & 4.0 & 1 & 14 & Sapium sebiferum \\
\hline 19 & $11 \mathrm{NE} 01 \mathrm{C}$ & WTS & Shatin Pass Rd & 16 & 6 & 1 & 4.8 & 1 & 8 & Oroxylum indicum \\
\hline 20 & $11 \mathrm{NE} 01 \mathrm{C}$ & WTS & Chuk Yuen Rd & 17 & 10 & 1 & 2.9 & 3 & 1 & Bischofia javanica \\
\hline 21 & $11 \mathrm{NE} 01 \mathrm{C}$ & WTS & Nga Chuk St & 18 & 9 & 1 & 3.6 & 3 & 7 & Brachychiton acerifolius \\
\hline 22 & $11 \mathrm{NE} 01 \mathrm{C}$ & WTS & Shatin Pass Rd & 19 & 10 & 1 & 3.0 & 3 & 25 & Sapium sebiferum \\
\hline 23 & $11 \mathrm{NE} 01 \mathrm{C}$ & WTS & Tsz Wan Shan Rd & 20 & 2 & 1 & 3.8 & 1 & 6 & Michelia champaca \\
\hline 24 & $11 \mathrm{NE} 01 \mathrm{C}$ & WTS & Tsz Wan Shan Rd & 21 & 2 & 1 & 3.8 & 1 & 10 & Michelia champaca \\
\hline 25 & 11NE01D & WTS & Tsz Wan Shan Rd & 1 & 10 & 1 & 3.2 & 3 & 2 & Spathodea campanulata \\
\hline
\end{tabular}


$\mathrm{ft}$; large, 10 to $15 \mathrm{~m}$ [33 to $49.5 \mathrm{ft}$ ]; medium, 5 to $10 \mathrm{~m}$ [16.5 to $33 \mathrm{ft}]$; small, less than $5 \mathrm{~m}$ [16.5 ft]) and crown spread of the exceptionally large and large trees (less than $15 \mathrm{~m}[49.5 \mathrm{ft}]$ and greater than $15 \mathrm{~m}$ [49.5 ft] crown diameter) were used to match sites with species. Additional botanical attributes were assessed such as growth form, attractive flowers, native versus exotic origin, and hardiness.

The tree survey data confirm the conservative species selection in both government and private projects with overreliance on popular species (Table 3) and implications on disease resistance and landscape quality (Raupp et al. 2006). The species homogenization phenomenon (Attorre et al. 2000) has spread from old to new neighborhoods. The species frequency profile could pinpoint the candidates to be weaned, including some excessively planted palms. The strong preference for exotics and the lack of species with attractive blooms could be consciously rectified. The tendency to plant trees with small final dimensions in large planting sites would need some attention. The obstacles to the wider use of natives such as the lack of supply by the landscape trade, inadequate practical experience on their suitability for urban use, and meager scientific information could be overcome by relevant policies and actions. An official species palette and guideline on species selection and matching with site conditions could be established by a coalition of landscape professionals and researchers.

The existing species composition and choice highlights the supply-led situation by local tree nurseries, which could gradually be adapted to a demand-led scenario. The seed collection and propagation techniques of local nurseries could be upgraded by training and demonstration schemes to meet the changing demands (Sæbø et al. 2005). Uncommon, rare natives with good performance as registered by the tree survey could be targeted for suitability testing. The choice of species in future planting programs could aim at adjusting the present imbalance in species composition and to enhance urban floristic biodiversity (Santamour 1990; Frank et al. 2006), which could bring collateral benefits to urban wildlife. Native species with the potential to supply suitable shelter and forage to indigenous wildlife could be targeted. In view of the frequent typhoon attack, the empiric tree performance data could recognize species that are tolerant or susceptible to wind damage. Overall, the results hint that future species choice could extend from aesthetic to ecologic and social considerations (Banks and Brack 2003).

The results also yield information on the type and magnitude of construction damages on trees and provide hints to minimize such impacts (Ames and Dewald 2003; Jim 2003). The old trees that grow spontaneously on old stone walls, a unique urban ecologic feature of the city, deserve special conservation efforts (Jim 1998a). The results identify some old or haphazard trees that are approaching their useful and safe lifespan, that demand a well-planned removal and replacement program. The findings on the cracked and raised pavement of sidewalks pinpoint the species with vigorous roots that could be avoided in confined paved areas.

A 5-year planting plan was designed to cover the ten urban districts (Table 7). The total number of plantable trees was divided into five approximately equal portions to be spread over 5 years. Rather than following strictly objective criteria in using the potential sites, some general principles were adopted in assigning priority in the planting program. Sites situated in neighborhoods with little or no existing trees, and sites that were more readily available, were targeted first. In addition, localities with high development density and poor environmental condition, that could benefit more from early introduction of greenery, were tackled as soon as possible. The plan should not be regarded as rigid and definitive. Instead, it could be appropriately modified to match the changing opportunities and constraints encountered in the course of implementation.

\section{CONCLUSIONS}

The methods developed for the detailed field evaluation of roadside trees provided useful data to study the intimate relationship between tree growth and the tight urban fabric in a dense city environment. The unique features of the field technique are the microscale assessment and measurement of the planting site and tree dimensions to highlight the intense conflicts between trees and urban structures. The inclusion of a survey of potential planting sites expanded the study. The proposed framework for the systematic identification, characterization, and use of potential planting sites in crowded streetside environs could be applied to other cities. Interpretation of the results permitted understanding of the arboricultural problems that commonly beset roadside trees in a cramped and stressful habitat and offered hints to design planting site, select species, and adjust tree planting and maintenance practices to enhance growth. The experience could be shared with Asian, African, and South American cities, which are commonly densely packed, and with the core commercial heart of Western cities, which have a similar tight town plan and tree growth confinements.

Acknowledgments. The grant supports kindly furnished by the municipal council and the Seed Funding for Basic Research scheme of the University of Hong Kong are gratefully acknowledged. I also thank the field assistance provided by student helpers of the University of Hong Kong.

\section{LITERATURE CITED}

Alvarez, I.A., G. Del Nero Velasco, H.S. Barbin, A.M.L.P. Lima, and H.T.Z. do Couto. 2005. Comparison of two sampling methods for estimating urban tree density. Journal of Arboriculture 31:209-214.

American Forests. 2004. CITYgreen for ArcGIS: Calculating the Value of Nature. American Forests, Washington, DC. 93 pp.

Ames, B., and S. Dewald. 2003. Working proactively with developers to preserve urban trees. Cities (London, England) 20:95-100.

Attorre, F., M. Bruno, F. Francesconi, R. Valenti, and F. Bruno. 2000. Landscape changes of Rome through tree-lined roads. Landscape and Urban Planning 49:115-128.

Banks, J.C.G., and C.L. Brack. 2003. Canberra's urban forest: Evolution and planning for future landscapes. Urban Forestry and Urban Greening 1:151-160.

Bradshaw, A.D., B. Hunt, and T. Walmsley. 1995. Trees in the Urban Landscape: Principles and Practice. E \& FN Spon, London, UK. 272 pp.

Bühler, O., P. Kristoffersen, and S.U. Larsen. 2007. Growth of street trees in Copenhagen with emphasis on the effect of different establishment concepts. Arboriculture and Urban Forestry 33:330-337.

Chacalo, A., A. Aldama, and J. Grabinsky. 1994. Street tree inventory in Mexico City. Journal of Arboriculture 20:222-226.

Cheng, S., J.R. McBride, and K. Fukunari. 2000. The urban forest of Tokyo. Arboricultural Journal 23:379-392.

D'Amato, N.E., T.D. Sydnor, and D.K. Struve. 2002. Urban foresters identify Ohio's tree needs. Journal of Arboriculture 28:291-301.

Dwyer, J.F., D.J. Nowak, and M.H. Noble. 2003. Sustaining urban forest. Journal of Arboriculture 29:49-55. 
Dwyer, M.C., and R.W. Miller. 1999. Using GIS to assess urban tree canopy benefits and surrounding greenspace distributions. Journal of Arboriculture 25:102-107.

Frank, S., G. Waters, R. Beer, and P. May. 2006. An analysis of street tree population of Greater Melbourne at the beginning of the 21st century. Arboriculture and Urban Forestry 32:155-163.

Greig-Smith, P. 1983. Quantitative Plant Ecology. 3rd ed. Blackwell, Oxford, UK. $359 \mathrm{pp}$.

Grey, G.W., and F.J. Deneke. 1986. Urban Forestry. 2nd ed. Wiley, New York, NY. 299 pp.

Harris, R.W., J.R. Clark, and N.P. Matheny. 2004. Arboriculture: Integrated Management of Landscape Trees, Shrubs and Vines. 4th ed. Prentice Hall, Upper Saddle River, NJ. 687 pp.

Herz, R., H. Schroeder, P. Stahre, Ö. Stal, and S. Woodward. 2003. Towards the integrated management of urban vegetation and infrastructure, pp. 1-10. Final Report of COST C3 Working Group on Vegetation and Urban Civil Engineering. European Cooperation in the field of Scientific and Technical Research, Council of the European Union, Brussels, Belgium.

Hou, H.Z. 1956. The Flora of Guangzhou. Science Press, Beijing, China. 953 pp.

Jaenson, R., N. Bassuk, S. Schwager, and D. Headley. 1992. A statistical method for the accurate and rapid sampling of urban street tree populations. Journal of Arboriculture 18:171-183.

Jim, C.Y. 1986. Urban Tree Survey 1985: Pavement Trees Managed by the Urban Council. Urban Council, Hong Kong. 84 pp.

1989. Tree canopy characteristics and urban development in Hong Kong. Geographical Review 79:210-225.

- 1990. Trees in Hong Kong: Species for Landscape Planting. Hong Kong University Press, Hong Kong. 434 pp.

- 1994a. Champion Trees in Urban Hong Kong. Hong Kong Flora and Fauna Series. Urban Council, Hong Kong. 295 pp. 1994b. Urban Tree Survey 1994: Roadside Trees Managed by the Urban Council. Vols. I to VI. Urban Council, Hong Kong.

. 1998a. Old stone walls as an ecological habitat for urban trees in Hong Kong. Landscape and Urban Planning 42:29-43.

1998b. Soil compaction at tree planting sites in urban Hong Kong, pp. 166-178. In: Watson, G.W., and D. Neely (Eds.). The Landscape Below Ground II. International Society of Arboriculture, Champaign, IL.

- 1998c. Physical and chemical properties of a Hong Kong roadside soil in relation to urban tree growth. Urban Ecosystems 2: $171-181$.

- 2000. Trees in Major Urban Parks in Hong Kong. Vols. I to IV. Leisure and Cultural Services Department, Hong Kong.

. 2003. Protection of urban trees from trenching damage in compact city environments. Cities (London, England) 20:87-94.

- 2004a. Spatial differentiation and landscape-ecological assessment of heritage trees in urban Guangzhou (China). Landscape and Urban Planning 69:51-68.

. 2004b. Green space preservation and allocation for sustainable greening in compact cities. Cities (London, England) 21:311-320.

. 2005. Monitoring the performance and decline of heritage trees in urban Hong Kong. Journal of Environmental Management 74: $161-172$.

Jim, C.Y., and S.S. Chen. 2003. Comprehensive greenspace planning based on landscape ecology principles in compact Nanjing city, China. Landscape and Urban Planning 65:95-116.

Jim, C.Y., and W.Y. Chen. 2008. Pattern and divergence of tree communities in Taipei's main urban green spaces. Landscape and Urban Planning 84:312-323.

- 2008. Assessing the ecosystem service of air pollution removal by urban vegetation in Guangzhou (China). Journal of Environmental Management (in press).

Jim, C.Y., and H.T. Liu. 2001. Species diversity of three major urban forest types in Guangzhou City, China. Forest Ecology and Management 146:99-114.
Johannsen, H.J. 1975. Municipal tree survey and urban tree inventory. Journal of Arboriculture 2:71-74

Lewis, B.L., and J.G. Boulahanis. 2008. Keeping up the urban forest: Predictors of tree maintenance in small southern towns in the United States. Arboriculture and Urban Forestry 34:41-46.

Lin, T.S. 1960. Illustrations of Native and Introduced Ligneous Plants of Taiwan. Vols. I and II. College of Agriculture, National Taiwan University, Taipei, Taiwan. $1350 \mathrm{pp}$.

Lonsdale, D. 2000. Hazards from Trees: A General Guide. Forestry Commission, Edinburgh, UK. 28 pp.

Maco, S.E., E.G. McPherson, J.R. Simpson, Q. Xiao, and P.J. Peper. 2004. City of North Vancouver, Urban Forest Master Plan Phase II Street Tree Master Plan, Backgrounder. USDA Forest Service, Center for Urban Forest Research, Pacific Southwest Research Station, Albany, CA. 32 pp.

Matheny, N.P., and J.R. Clark. 1994. A Photographic Guide to the Evaluation of Hazard Trees in Urban Areas. 2nd ed. International Society of Arboriculture, Savoy, IL. 85 pp.

McPherson, E.G. 2003. A benefit-cost analysis of ten street tree species in Modesto, California, U.S. Journal of Arboriculture 29:1-8.

McPherson, E.G., J. McCarter, and F. Baker. 1985. A microcomputerbased park tree inventory system. Journal of Arboriculture 11: 177-181.

McPherson, E.G., D. Nowak, G. Heisler, S. Grimmpnd, C. Souch, R. Grant, and R. Rowntree. 1997. Quantifying urban forest structure, function, and value: The Chicago urban forest project. Urban Ecosystems 1:49-61.

Miller, R.W. 1996. Urban Forestry: Planning and Managing Urban Greenspaces. 2nd ed. Prentice Hall, Englewood Cliffs, NJ. 502 pp.

Mueller-Dombois, D., and H. Ellenberg. 1974. Aims and Methods of Vegetation Ecology. John Wiley \& Sons, New York, NY. 547 pp.

Nowak, D.J. 1993. Historical vegetation change in Oakland and its implications for urban forest management. Journal of Arboriculture 19:313-319.

Nowak, D.J., and D.E. Crane. 2000. The urban forest effects (UFORE) model: Quantifying urban forest structure and functions, pp. 714-720. In: Hansen, M., and T. Burk (Eds.). Proceedings Integrated Tools for Natural Resources Inventories in the 21st Century. IUFRO Conference, 16-20 August 1998, Boise, ID. General Technical Report NC-212, US Department of Agriculture, Forest Service, North Central Research Station, St. Paul, MN.

Nowak, D.J., D.E. Crane, J.C. Stevens, and M. Ibarra. 2000. Brooklyn's Urban Forest. General Technical Report NE-290, US Department of Agriculture, Forest Service, Northeastern Research Station, Newtown Square, PA. 107 pp.

Pauleit, S., and F. Duhme. 2000. GIS assessment of Munich's urban forest structure for urban planning. Journal of Arboriculture 26: 133-141.

Pauleit, S., N. Jones, G. Garcia-Martin, J.L. Garcia-Valdecantos, L.M. Rivière, L. Vidal-Beaudet, M. Bodson, and T.B. Randrup. 2002. Tree establishment practice in towns and cities-Results from a European survey. Urban Forestry and Urban Greening 1:83-96.

Poracsky, J., and M. Scott. 1999. Industrial-area street trees in Portland, Oregon. Journal of Arboriculture 25:9-17.

Raupp, M.J., A.B. Cumming, and C. Raupp. 2006. Street tree diversity in eastern North America and its potential for tree loss to exotic borers. Arboriculture and Urban Forestry 32:297-304.

Sæbø, A., Z. Borzan, C. Ducatillion, A. Hatzistathis, T. Lagerström, J. Supuka, J.L. García-Valdecantos, F. Rego, and J. Van Slycken. 2005. The selection of plant materials for street trees, park trees and urban woodland, pp. 257-280. In: Konijnendijk, C.C., K. Nilsson, T.B. Randrup, and J. Schipperijn (Eds.). Urban Forests and Trees: A Reference Book. Springer, Berlin, Germany.

Santamour, F. 1990. Trees for urban planting: Diversity, uniformity and common sense, pp. 57-65. In: Proceedings of 7th Confederation of Metropolitan Tree Improvement Alliance (Metria 7). Morton Arboretum, Lisle, IL. 
Schroeder, H., J. Flannigan, and R. Coles. 2006. Residents' attitudes toward street trees in the UK and US communities. Arboriculture and Urban Forestry 32:236-246.

Schroeder, H.W., T.L. Green, and T.J. Howe. 2003. Community tree programs in Illinois, US: A statewide survey and assessment. Journal of Arboriculture 29:218-225.

Seaby, R.M.H., and P.A. Henderson. 2004. Species Diversity and Richness (III). Pisces Conservation, Lymington, Hampshire, UK. 56 pp.

Shigo, A.L. 1991. Modern Arboriculture: A Systems Approach to the Care of Trees and Their Associates. Shigo and Trees, Associates, Durham, NH. 424 pp.

South China Institute of Botany. 1987, 1991, 1995, 2000, 2003, 2005 , 2006. The Flora of Guangdong Province. Vols. 1-7. Science Press of Guangdong, Guangzhou, China. 3000 pp.

Tate, R.L. 1985. Uses of street tree inventory data. Journal of Arboriculture 11:210-213.

Thrower, S.L. 1988. Hong Kong Trees: Omnibus Volume. Urban Council, Hong Kong. 438 pp.

Tyrväinen, L., and A. Miettinen. 2000. Property prices and urban forest amenities. Journal of Environmental Economics and Management 39:205-223.

Warrick, R.B., and C.F. Williams. 1993. A computerized street tree inventory system for small cities using Lotus 1-2-3. Journal of Arboriculture 19:139-142.

Watson, G.W., and E.B. Himelick. 1997. Principles and Practice of Planting Trees and Shrubs. International Society of Arboriculture, Savoy, IL. 200 pp.

Weinstein, G. 1983. The central park tree inventory: A management model. Journal of Arboriculture 9:259-262.

Widdicombe, R.C., and B. Carlisle. 1999. Geographic information and global positioning systems for tree management. Journal of Arboriculture 25:175-178.

Wu, C.X., Q.F. Xiao, and E.G. McPherson. 2008. A method for locating potential tree-planting sites in urban areas: A case study of Los Angeles, USA. Urban Forestry and Urban Greening 7:65-76.

\author{
C.Y. Jim \\ Chair Professor of Geography \\ The University of Hong Kong \\ Room 301, Hui Oi Chow Science Building \\ Pokfulam Road \\ Hong Kong \\ hragjcy@hkucc.hku.hk
}

Résumé. Les inventaires des forêts urbaines de la cité à l'environnement dense de Hong Kong ont été initiés en 1985 et régulièrement mis à jour par la suite. Les arbres de rues ont été évalués en premier dans le recensement des arbres suivis ensuite par ceux dans les parcs urbains, les propriétés publiques et les habitats particuliers tels les vieilles enceintes de pierre ou les spécimens spéciaux comme les arbres historiques. La méthodologie d'inventaire visait à collecter des données détaillées afin de connaître à la fois la condition des arbres ainsi que les interactions entre les arbres et leur environnement. De l'information détaillée a été glanée, avec l'aide d'assistants bien entrainés, sur le site de l'arbre, l'espace de développement, la structure de l'arbre ainsi que les défauts structuraux et les désordres de santé. Une fiche d'inventaire a été mise au point, testée et raffinée pour obtenir des réponses à partir de choix multiples ou de mesures directes afin de minimiser la subjectivité et les erreurs dans l'entrée et l'enregistrement des données. L'étude a aussi identifié les sites potentiels de plantation, en enregistrant des données sur les conditions potentielles de développement, les caractéristiques de site et les dimensions. Les données de terrain ont été déterminées de telle manière à être quantitatives ou convertibles en rangs ordinaux dans le but de faciliter l'analyse statistique. La localisation des arbres ainsi que les sites de plantation ont été marqués sur une carte à grande échelle pour permettre une analyse spatiale. En plus de l'analyse statistique, des attributs de communauté écologique et des indices de design sur mesure ont été utilisés pour évaluer la structure de la forêt urbaine. Cette méthode multi-usage pourrait être ajustable de manière appropriée au sein d'autres villes denses.

Zusammenfassung. 1985 wurden in dem dichten Stadtgebiet von Hong Kong Aufnahmen des urbanen Waldbestands durchgeführt und hinterher regelmäßig aktualisiert. Die Straßenbäume und anschließend die Stadtparkanlagen, öffentliche Anlagen, spezielle Standorte wie alte Steinmauern oder Naturdenkmale wurden mittels eines Wertermittlungsverfahrens erfasst und in diesem Bericht dargestellt. Die Erhebungsmethode zielte darauf ab, umfassende Daten zum Zustand der Bäume und der Interaktionen am Standort zu sammeln. Mit der Hilfe von gut ausgebildeten Assistenten wurden detaillierte Informationen zum Standort, Baumscheibe, Baumstruktur, Defekte und Krankheiten erfasst. Es wurde ein Erfassungsprotokoll entwickelt, getestet und überarbeitet, um überlappende Antwortmöglichkeiten zu vereinzeln und die Fehler in der Datenaufnahme zu minimieren. Die Studie identifizierte auch potentielle Pflanzstandorte, indem sie die Wachstumsbedingungen, Standortcharakteristika und Dimensionen registrierte. Die Daten waren entweder quantitativ auszuwerten oder konvertierbar für Methoden der statistischen Analyse. Die Baumstandorte und Pflanzflächen wurden auf großen Plänen vermerkt, um eine räumliche Analyse zu ermöglichen. Neben der statistischen Analyse wurden auch der ökologische Nutzen und kundenspezifische Aspekte erfasst, um die urbane Forststruktur zu untersuchen. Diese multifunktionale Methode kann möglicherweise auch für andere, ähnliche Regionen verwendet werden.

Resumen. Se iniciaron estudios de bosques en ambientes urbanos compactos de Hong Kong en 1985 y regularmente actualizados desde entonces. Los árboles de alineación fueron evaluados primero en un censo y reportados en este artículo, seguidos por parques urbanos, parques públicos estatales y hábitats especiales tales como paredes de piedra antigua o especímenes especiales tales como árboles patrimoniales. El método de levantamiento intenta colectar datos tanto de las condiciones del árbol como las de las interacciones ambientales. Se distribuyó información detallada en tres sitios con la ayuda de asistentes bien entrenados, espacio de crecimiento de los árboles, estructura del árbol, defectos y desórdenes de los árboles. Se diseño un formato de registro de campo, así como una prueba piloto, y se refinó para solicitar respuestas a múltiples posibilidades o mediciones directas, para minimizar la subjetividad y errores en la entrada y el registro de los datos. El estudio también identificó sitios potenciales de plantación, registrando condiciones apropiadas para el crecimiento de los árboles, características del sitio y dimensiones. Los datos de campo fueron designados en rangos ordinales o cuantitativos para facilitar el análisis estadístico. Las localidades de los árboles y los sitios de plantación fueron marcados en mapas a escala grande para permitir el análisis espacial. Además del análisis estadístico, los atributos ecológicos de la comunidad y los índices fueron usados para evaluar la estructura del bosque urbano. El método multipropósito podría ser ajustado apropiadamente para usarse en otras áreas urbanas compactas. 